\title{
Korelasi Antara Kemampuan Berpikir Kritis dengan Penguasaan Kompetensi Pengetahuan IPS
}

\author{
Maria Yosi Anggraeni ${ }^{1 *}$, I Ketut Adnyana Putra ${ }^{2}$ \\ ${ }^{12}$ Jurusan Pendidikan Guru Sekolah Dasar, FIP, Universitas Pendidikan Ganesha, Indonesia
}

\section{A R T I CLEINFO \\ Article history: \\ Received 18 December 2018 \\ Received in revised form 30 December 2018 Accepted 15 January 2019 \\ Available online 20 \\ February2019}

\section{Kata Kunci:}

Kemampuan Berpikir Kritis, Penguasaan Kompetensi Pengetahuan IPS

Keywords:

Critical Thinking Ability, Mastery of Knowledge Competence IPS

\begin{abstract}
A B S T R A K
Penelitian ini bertujuan untuk mengetahui korelasi antara kemampuan berpikir kritis dengan penguasaan kompetensi pengetahuan IPS siswa kelas IV SD Gugus I Mengwi, pada tahun pelajaran 2017/2018. Jenis penelitian ini adalah penelitian ex post facto. Populasi dari penelitian ini merupakan seluruh siswa kelas IV SD yang berada di Gugus I Mengwi Tahun Pelajaran 2017/2018 yang memiliki jumlah populasi 147 siswa. Penentuan sampel menggunakan teknik proporsional simpel random sampling dengan taraf kesalahan 5\% dan diperoleh banyak sampel dari populasi sejumlah 105 siswa. Data kemampuan berpikir kritis diperoleh melalui tes esai dan data penguasaan kompetensi pengetahuan IPS didapatkan melalui pencatatan dokumen yaitu nilai Ujian Akhir Semester (UAS) semester I.. Berdasarkan hasil analisis maka diperoleh $r_{\text {xyhitung }}=0,764$. Pada taraf signifikansi $5 \%$, dan $n=105$ maka diperoleh $r_{\text {xytabel }}=0,195$. Karena $r_{\text {xyhitung }}=0,764>r_{\text {xytabel }}=0,195$ maka dapat diartikan bahwa $\mathrm{H}_{0}$ yang berbunyi tidak terdapat korelasi antara kemampuan berpikir kritis dengan penguasaan kompetensi pengetahuan IPS siswa kelas IV SD Gugus I Mengwi ditolak dan $\mathrm{H}_{\mathrm{a}}$ diterima. Jadi dapat disimpulkan bahwa terdapat korelasi antara kemampuan berpikir kritis dengan penguasaan kompetensi pengetahuan IPS siswa kelas IV SD Gugus I Mengwi Tahun Pelajaran 2017/2018, dengan arah korelasi positif, artinya semakin tinggi kemampuan berpikir kritis semakin meningkat penguasaan kompetensi pengetahuan IPS.
\end{abstract}

A B S T R A C T

This research aims to know the correlation between critical thinking ability with mastery of knowledge competence IPS grade IV elementary cluster I Mengwi, in lesson 2017/2018. This type of research is the research of ex post facto. The population of this research constitutes the entire grade IV elementary school located in cluster I Mengwi 2017/2018 lesson that year had a total population of 147 students. Determination of a sample using simple proportional random sampling technique with $5 \%$ error level and acquired a lot of samples from a population a number of 105 students. Data critical thinking ability gained through essays test the competency of knowledge mastery of data obtained through document recording, IPS, namely the value of the final Semester Exams (UAS) semester I. Based on the results of the analysis of the obtained $r_{x y h i t u n g}=0,764$. On the level of significance of $5 \%$ and $n=105$, then retrieved $r_{x y t a b e l}=0,195$. Because $r_{x y h i t u n g}=0,764>r_{x y t a b e l}=0,195$ then it can be interpreted that the $\mathrm{H}_{0}$ that reads there is no correlation between critical thinking ability with mastery of knowledge competence IPS grade IV elementary cluster I Mengwi rejected and accepted Ha. So it can be concluded that there is a correlation between critical thinking ability with mastery of knowledge competence IPS grade IV elementary cluster I Mengwi years lessons 2017/2018, with the direction of the positive correlations, meaning that the higher thinking ability increasing mastery of critical knowledge competence IPS.

\footnotetext{
${ }^{1}$ Corresponding author.

E-mail addresses: yosi.anggraeni@undiksha.ac.id (Maria Yosi Anggraeni)
} 


\section{Pendahuluan}

Perkembangan zaman yang begitu pesat menuntut adanya peningkatan mutu pendidikan Indonesia agar dapat menghasilkan sumber daya manusia yang memiliki kompetensi tinggi. Pendidikan sangat berguna untuk mencerdaskan kehidupan bangsa dan meningkatkan mutu bangsa secara menyeluruh. Seperti yang ditegaskan dalam Undang-undang Nomor 20 tahun 2003 tentang Sistem Pendidikan Nasional menegaskan bahwa, Pendidikan adalah usaha sadar dan terencana untuk mewujudkan suasana belajar dan proses pembelajaran agar peserta didik secara aktif mengembangkan potensi dirinya untuk memiliki kekuatan spiritual keagamaan, pengendalian diri, kepribadian, kecerdasan akhlak mulia, serta keterampilan yang diperlukan oleh dirinya, masyarakat, bangsa dan negara. Selain itu pengertian pendidikan menurut Susanto (2013:85) yaitu, Pendidikan adalah upaya terorganisasi, berencana dan berlangsung secara terus-menerus sepanjang hayat untuk membina anak didik menjadi manusia paripurna, dewasa, dan berbudaya. Untuk mencapai pembinaan ini asas pendidikan harus berorientasi pada pengembangan seluruh aspek potensi anak didik, diantaranya aspek kognitif, afektif, dan berimplikasi pada aspek psikomotorik.

Jadi pendidikan adalah memiliki tujuan utama yaitu untuk membentuk warga negara yang memiliki skill dan ketahanan mental yang baik dalam menjalani kehidupannya. Kesadaran masyarakat terhadap pentingnya pendidikan sesungguhnya sudah mulai tumbuh. Masyarakat menyadari pendidikan merupakan investasi jangka panjang bagi diri sendiri maupun anak-anaknya. Dengan berbekal pendidikan yang cukup mereka dapat bersaing dalam kerasnya dunia kerja, bekerja untuk memenuhi kebutuhan sehari-hari dan menjamin kelangsungan hidup mereka. Karena itulah masyarakat kini menempatkan pendidikan sebagai kebutuhan yang bersifat primer. Orang tua berlomba-lomba untuk memberikan pendidikan terbaik bagi anak-anak mereka melalui lembaga-lembaga pendidikan negeri maupun swasta yang sudah sangat banyak ada di lingkungan sekitar mereka. Antusias dan kesadaran masyarakat terhadap pentingnya pendidikan seharusnya dibarengi dengan pembenahan mutu dan kualitas pendidikan.

Dalam pendidikan yang bersifat formal secara khusus telah ditetapkan standar pendidikan yang dimuat dalam Peraturan Pemerintah Indonesia No. 19 Tahun 2005 tentang Standar Nasional Pendidikan (SNP) yaitu "Standar isi, standar kompetensi lulusan, standar pendidik dan tenaga kependidikan, standar pengelola, standar penilaian, standar sarana dan prasarana, standar pembiayaan, dan standar proses". Standar-standar tersebut dapat digunakan untuk menentukan keberhasilan atau untuk merancang rencana kerja yang lebih baik dari waktu ke waktu, jika standar tersebut sudah terpenuhi maka mutu pendidikan sudah pasti meningkat. Standar-standar tersebut juga menjadi acuan dalam melaksanakan pembangunan di bidang pendidikan.

Pendidikan formal dapat ditempuh di SD, SMP, SMA, dan perguruan tinggi. Dalam pendidikan formal tingkat SD siswa memperoleh pendidikan yang mampu membuat mereka menjadi individu yang berkarakter, yang tentunya akan sangat bermanfaat untuk menjalani kehidupan dimasa depan. SD merupakan tempat untuk memenuhi rasa ingin tahunya terhadap dunia baik terkait dengan pengetahuan maupun sikap sosial, pendidikan di SD menjadi fondasi siswa dalam membangun pengetahuan mereka secara berkesinambungan. Karena itulah mutu pendidikan di SD harus diperhatikan agar tetap dalam kualitas yang baik. Terkait dengan mutu pendidikan di SD, pemerintah telah menetapkan kebijakankebijakan untuk mengarahkan pendidikan di SD melaju ke arah yang tepat sehingga dapat mencapai tujuan yang diinginkan. Kebijakan tersebut salah satunya adalah dengan melakukan penyempurnaan kurikulum. Kebijakan ini sering mendapat respon yang negatif dikalangan tenaga pendidik karena dianggap merepotkan dan menimbulkan kebingungan. Dalam kurikulum ditetapkan tujuan dan prioritas pencapaian proses pembelajaran yang menjadi salah satu tolak ukur keberhasilan suatu proses pendidikan. "Kurikulum adalah seperangkat rencana dan pengaturan mengenai tujuan, kompetensi dasar, materi standar, dan hasil belajar, serta cara yang digunakan sebagai pedoman penyelenggaraan kegiatan pembelajaran untuk mencapai kompetensi dasar dan tujuan pendidikan" (Undang-Undang Nomor 20 Tahun 2003). Kurikulum 2013 dikembangkan atas teori berbasis kompetensi. Pendidikan berdasarkan kurikulum berbasis kompetensi dirancang untuk memberikan pengalaman belajar seluas-luasnya bagi siswa dalam mengembangkan kemampuan untuk bersikap, berpengetahuan, berketerampilan dan bertindak.

Guru sebagai penerjemah tujuan pendidikan yang tersurat dalam kurikulum kepada siswa. Guru mampu membentuk sumber daya manusia yang mampu menjalankan roda pembangunan bangsa Indonesia. Pengembangan sumber daya manusia yang berkualitas akan lebih efektif dilaksanakan dari usia dini. SD adalah gerbang pertama yang harus dilalui dalam mengembangkan individu yang mampu berkompetisi dalam dunia modern. Pentingnya posisi SD dalam pembangunan bangsa, juga diikuti dengan karakteristik siswa-siswanya yang berbeda dengan siswa usia SMP atau SMA dan pastinya perguruan 
tinggi. Siswa usia SD yang berumur 7-11 tahun berada dalam masa perkembangan kognitif operasional konkret (Piaget dalam Susanto).

Dalam masa ini siswa dapat dengan baik menangkap informasi terkait konsep yang dipelajari apabila disajikan gambaran nyata yang berhubungan dengan konsep tersebut. Sangat berbeda dengan siswa usia SMP atau SMA yang sudah mampu membayangkan sesuatu yang bersifat abstrak. Daya serap siswa akan materi yang disampaikan sangat baik jika pembelajaran dikemas dengan media-media konkret atau dengan pengalaman langsung.

"Belajar adalah suatu uasaha sadar yang dilakukan oleh individu dalam perubahan tingkah laku baik melalui latihan dan pengalaman yang menyangkut aspek-aspek kognitif, afektif, dan psikomotorik untuk memperoleh tujuan tertentu" Aunurrahman (2012:35). Bagi siswa, belajar merupakan sebuah proses interaksi antara berbagai potensi diri siswa (fisik, nonfisik, emosi, dan intelektual), interaksi siswa dengan guru, siswa dengan siswa lainnya, serta lingkungan dengan konsep dan fakta, interaksi dari berbagai stimulus dengan berbagai respons terarah untuk melahirkan perubahan. "Tujuan belajar adalah sejumlah hasil belajar yang menunjukkan bahwa siswa telah melakukan perbuatan belajar, yang umumnya meliputi pengetahuan, keterampilan dan sikap-sikap yang baru, yang diharapkan dapat dicapai oleh siswa" Jihad ( 2012:15).

Menurut Saputra (2016) tujuan dari proses pendidikan di sekolah dasar adalah agar siswa mampu memahami potensi diri, memiliki peluang, dan memahami tuntutan lingkungan serta dapat merencanakan masa depan mengenai serangkaian keputusan yang paling mungkin bagi dirinya. Tujuan akhir pendidikan dasar adalah diperolehnya pengembangan pribadi anak yang dapat membangun dirinya sendiri dan ikut serta bertanggung-jawab terhadap pembangunan bangsa, mampu melanjutkan ke tingkat pendidikan yang lebih tinggi, dan mampu hidup di masyarakat dan mengembangkan diri sesuai dengan bakat, minat, kemampuan, dan lingkungan. Materi pembelajaran IPS di SD yang syarat dengan konsep, pengertian, dan prinsip-prinsip abstrak, perlu mendapatkan perhatian yang serius agar tujuan pembelajaran lebih bermakna. Kebermaknaan tujuan pembelajaran ini, akan lebih baik dan efektif manakala bahan ajar dan tugas-tugas yang diberikan dirasakan akrab, intim, dan menyentuh diri siswa. Menurut Habibullah (2014) hasil belajar diartikan sebagai tingkat penguasaan yang dicapai oleh siswa dalam mengikuti proses pembelajaran sesuai dengan program pendidikan yang ditetapkan. Ini berarti bahwa hasil belajar adalah segala sesuatu yang dapat dilakukan atau dikuasai siswa sebagai pengalaman belajar. Pernyataan tersebut mengindikasikan bahwa bahwa hasil belajar adalah bagian terpenting dalam pembelajaran. Hasil yang didapat dalam proses belajar adalah penguasaan kompetensi materi yang diajarkan oleh guru. "Kompetensi merupakan sesuatu yang kompleks yang di dalamnya mengandung banyak aspek (ranah)" (Kosasih 2014:14). Kompetensi tersebut merupakan kemampuan yang dijadikan standar lulusan yang harus dimiliki oleh siswa. Untuk mengukur penguasaan kompetensi pengetahuan siswa dalam proses pembelajaran dilakukan proses penilaian atau evaluasi. Penilaian atau evaluasi dalam pembelajaran dimaksudkan untuk memperoleh informasi tentang perolehan belajar siswa seacara menyeluruh, baik pengetahuan, konsep, nilai, maupun proses. Dalam hal ini difokuskan pada mata pelajaran IPS. Ilmu Pengetahuan Sosial atau yang sering disingkat dengan IPS adalah suatu ilmu pengetahuan yang lebih banyak mengkaji tentang manusia dalam semua aspek kehidupan sosial dan interaksinya dalam masyarakat.

Menurut Purnomo (2016) ilmu Pengetahuan Sosial berbeda dengan disiplin ilmu yang monodisiplin.IPS mempunyai keterpaduan antar disiplin ilmu sosial. Geografi memberikan wawasan yang berkenaan dengan wilayah-wilayah, sejarah memberikan wawasan tentang peristiwaperistiwa yang terjadi pada masa lampau, ekonomi memberikan wawasan tentang berbagai macam kebutuhan manusia dan sosiologi atau antropologi memberikan wawasan yang berkenaan dengan nilai-nilai, kepercayaan, struktur sosial, lalu ilmu politik lebih kepada mengkaji hubungan antara warga dengan warga negaranya, serta negara dengan negaranya, dan psikologi membahas mengenai kondisi kejiwaan seseorang atau manusia.Sosiologi dan psikologi sosial merupakan ilmu-ilmu tentang perilaku seperti konsep peran, kelompok, institusi, proses interaksi dan kontrol sosial. Secara intensif konsep-konsep seperti ini digunakan ilmu-ilmu sosial dan studi-studi sosial. Menurut Surahman (2017) ilmu Pengetahuan Sosial adalah mata pelajaran di sekolah yang di desain atas dasar fenomena, masalah dan realitas sosial dengan pendekatan interdisipliner yang melibatkan berbagai cabang ilmu-ilmu sosial dan humaniora seperti kewarganegaraan, sejarah, geografi, ekonomi, sosiologi, antropologi, pendidikan. Karena itu, IPS dapat dikatakan sebagai studi mengenai perpaduan antara ilmu-ilmu dalam rumpun ilmu-ilmu sosial dan juga humaniora untuk melahirkan pelakupelaku sosial yang dapat berpartisipasi dalam memecahkan masalahmasalah sosio kebangsaan. Bahan kajiannya menyangkut peristiwa, seperangkat fakta, konsep dan generalisasi yang berkait dengan isu-isu aktual, gejala dan masalah-masalah atau realitas sosial serta potensi daerah. Kompetensi pengetahuan IPS adalah perubahan perilaku siswa yang mencerminkan kemampuan siswa terhadap penguasaan pembelajaran IPS dari segi pengetahuan setelah mengalami 
proses belajar. Menurut Susanto (2013:145), “tujuan utama pembelajaran IPS adalah untuk mengembangkan potensi peserta didik agar peka terhadap masalah sosial yang terjadi di masyarakat, memiliki sikap mental positif terhadap perbaikan segala ketimpangan yang terjadi, dan terampil mengatasi setiap masalah yang terjadi sehari-hari, baik yang menimpa dirinya sendiri maupun yang menimpa masyarakat". Tujuan pembelajaran IPS di SD bukan hanya memberikan bekal pengetahuan saja, tetapi juga memberikan bekal nilai dan sikap serta ketrampilan dalam kehidupan siswa di masyarakat, bangsa, dan negara dalam berbagai karakteristik. Melalui mata pelajaran IPS siswa diarahkan untuk dapat menjadi warga negara Indonesia yang demokratis dan bertanggung jawab, serta warga dunia yang cinta damai. Peranan mata pelajaran IPS sangat penting untuk mendidik siswa mengembangkan pengetahuan, sikap, dan keterampilan agar dapat mengambil bagian secara aktif dalam kehidupannya kelak sebagai anggota masyarakat dan warga negara yang baik.

Dalam mengikuti sebuah proses pembelajaran tidak selalu berjalan dengan mulus, terkadang ada siswa yang belum maksimal atau belum berhasil dalam belajar. Berhasil atau tidaknya seseorang dalam belajar disebabkan beberapa faktor yaitu faktor yang berasal dari dalam diri siswa dan dari luar diri siswa. Faktor inilah yang mempengaruhi prestasi belajar siswa. Pada dasarnya ada banyak faktor yang mempengaruhi prestasi belajar siswa. Sekolah merupakan salah satu faktor yang ikut menentukan keberhasilan siswa dalam belajar. Kualitas pengajaran di sekolah sangat ditentukan oleh guru. Guru dalam proses pembelajaran memegang peranan yang sangat penting. Pembelajaran di SD saat ini guru masih menganggap siswa sebagai objek, bukan sebagai subjek dalam pembelajaran sehingga guru dalam proses pembelajaran masih mendominasi aktivitas belajar. Siswa hanya menerima informasi dari guru secara pasif.

Dalam proses pembelajaran guru lebih sering menggunakan metode ceramah yang membuat pembelajaran menjadi kurang menarik dan membosankan. Metode ceramah yang digunakan guru dalam proses pembelajaran ini membuat siswa menjadi kurang aktif. Hal ini menyebabkan siswa menjadi kurang optimal dalam mengembangkan kemampuan berpikirnya. Sehingga menyebabkan banyak siswa yang mendaptkan nilai penguasaan kompetensi pengetahuan khususnya mata pelajaran IPS masih di bawah rata-rata. Dan banyak siswa yang belum menguasi kompetensi pengetahuan dengan baik. Guru SD hendaknya selalu berinovasi dan mengembangkan ide kreatif dalam mengemas pembelajaran. Hal ini untuk menjaga minat belajar siswa. Guru hendaknya mampu menyajikan sebuah pembelajaran yang menyenangkan, memberikan pengalaman belajar yang baru, serta melibatkan sikap-sikap sosial dalam pelaksanaannya. Jika hal tersebut dapat dilaksanakan oleh guru maka pembelajaran akan lebih efektif dan bermakna bagi siswa. Dengan melibatkan siswa dalam proses pembelajaran siswa dapat membangun pengetahuannya sendiri.

Dalam mengikuti dan memahami suatu pembelajaran diperlukan kemampuan berpikir. Kemampuan berpikir siswa yang diperlukan disini tidak hanya kemampuan berpikir kreatif tetapi juga kemampuan berpikir kritis dalam memecahkan sebuah masalah. Menurut Susanto (2013:121) "Berpikir kritis adalah suatu kegiatan melalui cara berpikir tentang ide atau gagasan yang berhubungan dengan konsep yang diberikan atau masalah yang dipaparkan". Sedangkan menurut Prihanti (2015:126) "Berpikir kritis adalah pemikiran yang masuk akal dan reflektif yang berfokus untuk memutuskan apa yang mesti dipercaya atau dilakukan. Berpikir dengan tujuan membuat keputusan masuk akal tentang apa yang diyakini atau dilakukan". Berpikir kritis juga dapat dipahami sebagai kegiatan menganalisis idea atau gagasan kearah yang lebih spesifik, membedakannya secara tajam, memilih, mengidentifikasi, mengkaji dan mengembangkannya kearah yang lebih sempurna. Berpikir kritis berkaitan dengan asumsi bahwa berpikir merupakan potensi yang ada pada manusia yang perlu dikembangkan untuk kemampuan yang optimal. Berdasarkan hal ini siswa akan memiliki rasa ingin tahu yang sangat besar dan mencoba memecahkan masalahnya. Setiap orang memiliki tingkat berpikir yang berbeda-beda.

Dengan demikian, salah satu yang mempengaruhi penguasaan pengetahuan siswa, terutama pengetahuan IPS siswa adalah tingkat berpikir siswa. Siswa yang memiliki kemampuan berpikir kritis yang kurang cenderung lebih sulit untuk memecahkan masalah dalam pembelajaran. Sementara siswa yang memiliki tingkat kemampuan berpikir yang tinggi terutama berpikir kritis akan dapat lebih menguasai materi pembelajaran. Selain itu, siswa yang memiliki kemampuan berpikir kritis akan dapat memecahkan masalah dalam kegiatan pembelajaran terutama dalam pelajaran IPS.

Dari uraian tersebut penelitian ini dilakukan untuk mengetahui apakah kemampuan berpikir kritis berkorelasi secara signifikan dengan penguasaan kompetensi pengetahuan IPS, penelitian tersebut dilakukan dengan judul "Korelasi Antara Kemampuan Berpikir Kritis Dengan Penguasaan Kompetensi Pengetahuan IPS Siswa Kelas IV SD Gugus I Mengwi Tahun Pelajaran 2017/2018”. 


\section{Metode}

Penelitian ini merupakan penelitian Ex Post Facto Korelasional karena penelitan ini bertujuan untuk mengetahui korelasi antara kemampuan berpikir kritis dengan penguasaan kompetensi pengetahuan IPS, dengan tidak memanipulasi variabel bebas atau menggali fakta yang sudah terjadi sebelumnya. Populasi dalam penelitian ini adalah siswa kelas IV SD Gugus I Mengwi tahun pelajaran 2017/2018 yang berjumlah 147 siswa. Berdasarkan tabel Issac and Michael, jumlah populasi yang terdapat di Gugus I Mengwi adalah 147 orang siswa dan jumlah sampel yang diambil berdasarkan tingkat kesalahan 5\% berjumlah 105 orang siswa. Pengambilan sampel dalam penelitian ini menggunakan teknik proporsional simpel random sampling yang artinya teknik pengambilan sampel secara acak dengan memperhatikan jumlah siswa dari masing-masing kelas sesuai dengan proporsi yang terdapat di dalam populasi tersebut.

Metode yang digunakan dalam pengumpulan data adalah metode teknik tes dan non tes. Teknik tes yang digunakan dalam penelitian ini yaitu tes esai dan teknik non tes yang digunakan yaitu pencatatan dokumen. Tes esai adalah alat ukur berupa tulisan memiliki item pertanyaan yang jawabannya dapat mempergunakan kata-kata sendiri. Dalam penelitian ini sesuai dengan data yang dikumpulkan, instrumen yang digunakan adalah tes esai kemampuan berpikir kritis, dan data tentang penguasaan kompetensi pengetahuan IPS siswa kelas IV SD Gugus I Mengwi tahun pelajaran 2017/2018 diperoleh dari pencatatan dokumen. Instrumen tes kemampuan berpikir kritis yang diberikan untuk mengetahui dan mengukur kemampuan kognitif siswa. Tes berpikir kritis ini terdiri dari 5 subtes. Penilaian pada instrumen ini menggunakan rubrik penilaian dengan rentang skor 1-5 dan dihitung dengan rumus sebagai berikut.

$$
\text { Nilai }=\frac{\text { Skor Mentah }}{\text { Skor Maksimum Ideal }} \times 100
$$

(Sudijono, 2015:318)

Pengujian instrumen dalam penelitian ini menggunakan validitas isi, validitas konstrak, validitas butir dan reliabilitas. Pencatatan dokumen yang digunakan untuk pengumpulan data penguasaan kompetensi pengetahuan IPS siswa kelas IV SD Gugus I Mengwi tahun pelajaran 2017/2018 dieroleh dari nilai UAS semester I.

Analisis dalam penelitian ini menggunakan analisis statistik inferensial. Teknik analisis data yang digunakan teknik korelasi product moment yang digunakan unuk mencari hubungan dua variabel yaitu variabel bebas dan variabel terikat dengan menggunakan data interval atau ratio. Untuk memenuhi persyaratan uji hipotesis maka diperlukan uji persyaratan analisis yaitu uji normalitas dan uji hipotesis statistik. Uji normalitas digunakan untuk menguji apakah data variabel bebas dan variabel terikat berdistribusi normal atau tidak, dengan cara menggunakan rumus chi-kuadrat dengan kriteria yang digunakan adalah dengan membandingkan nilai $\mathrm{X}^{2}$ tabel dengan $\mathrm{X}^{2}$ hitung pada taraf signifikansi $5 \%$ dengan ketentuan $\mathrm{X}^{2}$ hitung $<\mathrm{X}^{2}$ tabel maka data berdistribusi normal. Uji hipotesis statistik menggunakan korelasi product moment dengan mengetes antara variabel bebas $(\mathrm{X})$ dan variabel terikat $(\mathrm{Y})$. Hipotesis yang diuji dalam penelitian ini adalah $\mathrm{H}_{\mathrm{o}}$ yang berbunyi tidak terdapat korelasi yang signifikan antara kemampuan berpikir kritis dengan penguasaan kompetensi pengetahuan IPS siswa kelas IV SD Gugus I Mengwi tahun pelajaran 2017/2018, dengan kriteria yang digunakan dalam pengujian korelasi product moment ini yaitu dengan taraf signifikansi 5\%. Adapun ketentuan yang diuji dalam penelitian ini jika $r_{x y}$ hitung $>r_{x y t a b e l}$ maka $\mathrm{H}_{0}$ ditolak berarti terdapat korelasi antara kemampuan berpikir kritis (X) dengan penguasaan kompetensi pengetahuan IPS (Y) sebaliknya jika $r_{x y}$ hitung $<r_{x y}$ tabel maka $H_{0}$ diterima berarti tidak terdapat korelasi antara kemampuan berpikir kritis (X) dengan penguasaan kompetensi pengetahuan IPS (Y).

\section{Hasil dan Pembahasan}

Deskripsi Data Kemampuan Berpikir Kritis

Data mengenai konsep diri siswa kelas IV SD Gugus I Mengwi diperoleh melalui penyebaran tes esai. Sampel yang dibagikan tes esai berjumlah 105 responden dan diberikan 5 pernyataan.

Berdasarkan data nilai tes kemampuan berpikir kritis rata-rata siswa kelas IV SD Gugus I Mengwi Tahun Pelajaran 2017/2018 mendapatkan nilai 79,47. Dari data di atas dapat juga dilihat dalam bentuk grafik, sehingga dapat dilihat sebagai berikut: 


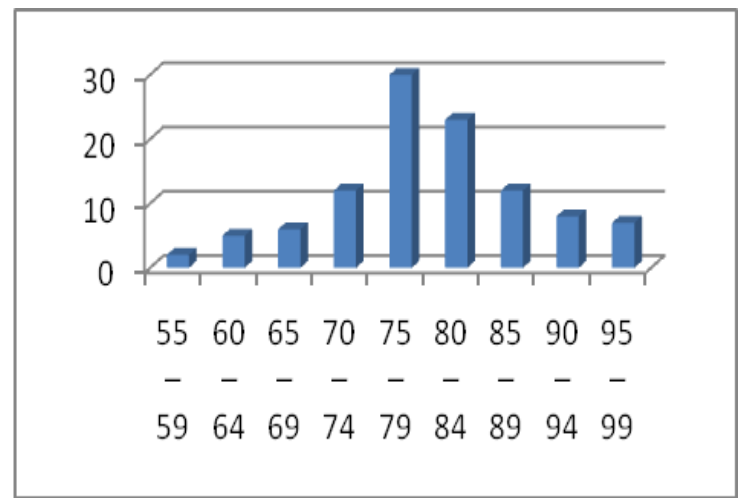

Gambar 1. Histogram Data Kemampuan Berpikir Kritis

Berdasarkan diagram tentang data kemampuan berpikir kritis dapat diketahui bahwa siswa yang mendapat nilai 55-59 sebanyak 2 orang, siswa yang mendapat nilai 60-64 sebanyak 5 orang, siswa yang mendapat nilai 65-69 sebanyak 6 orang, siswa yang mendapat nilai 70-74 sebanyak 12 orang, siswa yang mendapat nilai 75-79 sebanyak 30 orang, siswa yang mendapat nilai 80-84 sebanyak 23 orang, siswa yang mendapat nilai 85-89 sebanyak 12 orang, siswa yang mendapat nilai 90-94 sebanyak 8 orang, siswa yang mendapat nilai 95-99 sebanyak 7 orang, frekuensi nilai terbanyak terdapat pada kelas interval ke-5 yaitu 75-79, selanjutnya dapat dilihat data berikut ini tentang tingkat kategori kemampuan berpikir kritis siswa kelas IV SD Gugus I Mengwi Tahun Pelajaran 2017/2018.

Tabel 1. Pedoman Konversi PAP Skala Lima Kemampuan Berpikir Kritis

\begin{tabular}{cc}
\hline Persentase Kemampuan Berpikir Kritis & Kriteria Kemampuan Berpikir Kritis \\
\hline $90-100$ & Sangat Tinggi \\
$80-89$ & Tinggi \\
$65-79$ & Sedang \\
$55-64$ & Rendah \\
$0-54$ & Sangat Rendah \\
\hline
\end{tabular}

(Sumber: Agung, 2014:118)

Berdasarkan kategori kemampuan berpikir kritis diatas serta hasil analisis data, bahwa rerata dari konsep diri siwa kelas IV SD Gugus I Mengwi adalah 79,47. Berdasarkan data tersebut maka dapat disimpulkan bahwa nilai kemampuan berpikir kritis siswa kelas IV SD Gugus I Mengwi, tergolong kategori sedang.

Deskripsi Data Penguasaan Kompetensi Pengetahuan IPS

Data tentang nilai penguasaan kompetensi pengetahuan IPS diperoleh melalui pencatatan dokumen, dokumen tersebut adalah daftar nilai ulangan akhir semester 1. Pencatatan dokumen dilakukan sesuai dengan jumlah sampel yaitu 105 siswa kelas IV SD Gugus I Mengwi Tahun Pelajaran 2017/2018.

Berdasarkan data nilai penguasaan kompetensi pengetahuan IPS rata-rata siswa kelas IV SD Gugus I Mengwi Tahun Pelajaran 2017/2018 mendapatkan nilai 79,44. Dari data di atas dapat juga dilihat dalam bentuk grafik, sehingga dapat dilihat sebagai berikut:

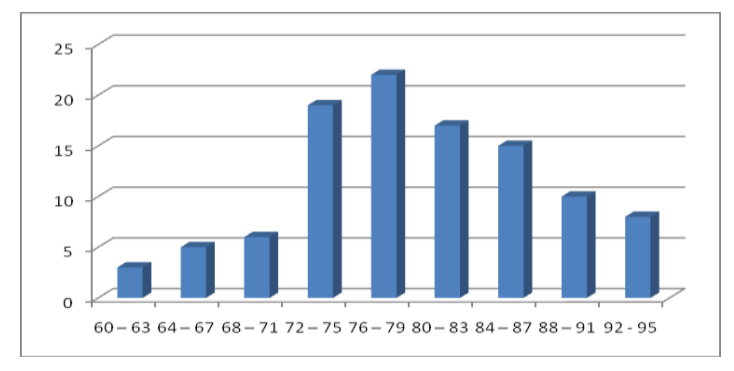

Gambar 2. Histogram Data Penguasaan Kompetensi Pengetahuan IPS 
Berdasarkan diagram tentang data nilai penguasaan kompetensi pengetahuan IPS dapat diketahui bahwa siswa yang mendapat nilai 60-63 sebanyak 3 orang, siswa yang mendapat nilai 64-67 sebanyak 5 orang, siswa yang mendapat nilai 68-71 sebanyak 6 orang, siswa yang mendapat nilai 72-75 sebanyak 19 orang, siswa yang mendapat nilai 76-79 sebanyak 22 orang, siswa yang mendapat nilai 80-83 sebanyak 17 orang, siswa yang mendapat nilai 84-87 sebanyak 15 orang, siswa yang mendapat nilai 88-91 sebanyak 10 orang, siswa yang mendapat nilai 92-95 sebanyak 8 orang, frekuensi nilai terbanyak terdapat pada kelas interval ke-5 yaitu 76-79, selanjutnya dapat dilihat data berikut ini tentang tingkat kategori penguasaan kompetensi pengetahuan IPS siswa kelas IV SD Gugus I Mengwi Tahun Pelajaran 2017/2018.

Tabel 2. Pedoman Konversi PAP Skala Lima Penguasaan Kompetensi Pengetahuan IPS

\begin{tabular}{cc}
\hline $\begin{array}{c}\text { Persentase Penguasaan Kompetensi Pengetahuan } \\
\text { IPS }\end{array}$ & $\begin{array}{c}\text { Kriteria Penguasaan Kompetensi } \\
\text { Pengetahuan IPS }\end{array}$ \\
\hline $90-100$ & Sangat Tinggi \\
$80-89$ & Tinggi \\
$65-79$ & Sedang \\
$55-64$ & Rendah \\
$0-54$ & Sangat Rendah \\
\hline & (Sumber:Agung,2014:118)
\end{tabular}

Berdasarkan kategori penguasaan kompetensi pengetahuan IPS di atas serta hasil dari analisis data, bahwa rerata dari penguasaan kompetensi pengetahuan IPS siswa kelas IV Gugus I Mengwi adalah 79,44. Berdasarkan data tersebut maka dapat disimpulkan bahwa nilai penguasaan kompetensi pengetahuan IPS siswa kelas IV SD Gugus I Mengwi, tergolong kategori sedang.

\section{Uji Prasyarat Analisis}

Uji normalitas kemampuan berpikir kritis (X) dan penguasaan kompetensi pengetahuan IPS (Y) menggunakan teknik uji Chi-Kuadrat $\left(\mathrm{x}^{2}\right)$. Nilai dari variabel X dan Y dapat dikatakan berdistribusi normal apabila $\mathrm{x}^{2}$ hitung $<\mathrm{x}^{2}$ tabel. Kreteria yang digunakan dengan membandingkan nilai $\mathrm{x}^{2}$ tabel dengan $\mathrm{x}^{2}$ hitung pada taraf signifikansi $5 \%$ dengan ketentuan $\mathrm{X}^{2}$ tabel $>\mathrm{X}^{2}$ hitung maka data berdistribusi normal. Hasil uji normalitas kemampuan berpikir kritis $(X)$ yaitu $\mathrm{x}^{2}$ hitung $=5,1$. Berdasarkan analisis maka diperoleh $\mathrm{X}^{2}$ hitung $=$ 5,1 dan menggunakan taraf signifikansi 5\% dengan menggunakan derajat kebebasan 5, maka diperoleh $\mathrm{x}^{2}$ tabel $=11,07$. Hal ini berati $\mathrm{x}^{2}$ hitung $5,1<\mathrm{x}^{2}$ tabel 11,07 maka dapat dinyatakan sebaran data berdistribusi normal. Sedangkan hasil uji normalitas penguasaan kompetensi pengetahuan IPS (Y) yaitu $x^{2}$ hitung $=5,3$. Berdasarkan analisis maka diperoleh $\mathrm{x}^{2}$ hitung $=5,3$ dan menggunakan taraf signifikansi $5 \%$ dengan menggunakan derajat kebebasan 5, maka diperoleh $x^{2}$ tabel $=11,07$. Hal ini berati $x^{2}$ hitung 5,3< $x^{2}$ tabel 11,07 maka dapat dinyatakan sebaran data berdistribusi normal. Hasil tersebut membuktikan bahwa data kedua variabel bebas dan terikat bersifat normal.

\section{Pengujian Hipotesis}

Setelah dilakukan uji prasyarat dan diketahui data berdistribusi normal, dilanjutkan uji hipotesis guna mengetahui adanya korelasi antar variabel. Uji hipotesis yang dilakukan adalah uji hipotesis dengan menggunakan teknik analisis product moment (variabel $\mathrm{X}$ dengan variabel $\mathrm{Y}$ ), maka untuk tujuan analisis data dirumuskan dalam hipotesis nol $\left(\mathrm{H}_{0}\right)$. Hipotesis yang dirumuskan yaitu $\mathrm{H}_{0}$ : Tidak terdapat korelasi yang signifkan antara kemampuan berpikir kritis dengan penguasaan kompetensi pengetahuan IPS siswa kelas IV SD Gugus I Mengwi Tahun Pelajaran 2017/2018.

Berdasarkan tabel penolong untuk mencari nilai $\mathrm{r}$ dengan menggunakan rumus product moment yaitu:

$$
r_{x y}=\frac{\mathrm{N} \sum \mathrm{XY}-\left(\sum X\right)\left(\sum Y\right)}{\sqrt{\left\{N \sum X^{2}-\left(\sum X\right)^{2}\right\}\left\{N \sum Y^{2}-\left(\sum Y\right)^{2}\right\}}}
$$

(Suharsimi, 2015:87)

dan dibantu menggunakan Microsoft excel 2007. Pengujian koefisien korelasi dengan rumus product moment diperoleh hasil $\mathrm{r}_{\mathrm{xy}}$ hitung $=0,764$. Untuk uji koefisien korelasi, digunakan nilai tabel product moment (r) untuk $\mathrm{n}=105$, pada taraf signifikansi 5\% diperoleh angka sebesar 0,195. Maka dapat dinyatakan $r_{x y h i t u n g}>r_{x y t a b e l}$. Ini berati nilai $r_{x y h i t u n g}$ signifikan dengan nilai 0,764 , sehingga $\mathrm{H}_{0}$ yang berbunyi 
tidak terdapat korelasi yang signifikan antara kemampuan berpikir kritis dengan penguasaan kompetensi pengetahuan IPS siswa kelas IV SD Gugus I Mengwi Tahun Pelajaran 2017/2018 ditolak dan $\mathrm{H}_{\mathrm{a}}$ diterima. Berdasarkan hasil perhitungan $r_{x y h i t u n g}$ dengan membandingkan $r_{x y t a b e l}$ dilihat dari hasilnya hal ini menunjukan bahwa terjadi korelasi, antara kemampuan berpikir kritis dengan penguasaan kompetensi pengetahuan IPS. Sedangkan arah korelasi, dari hasil penelitian ini yaitu arah korelasi positif berarti semakin tinggi kemampuan berpikir kritis yang dimiliki siswa maka semakin meningkat pula penguasaan kompetensi pengetahuan IPS.

Berdasarkan hasil analisis pengujian koefisien korelasi dengan rumus product moment diperoleh hasil $\mathrm{r}_{\text {xyhitung }}=0,764$. Untuk uji koefisien korelasi, digunakan nilai tabel product moment $(\mathrm{r})$ untuk $\mathrm{n}=$ 105, pada taraf signifikansi $5 \%$ adalah 0,195 . Maka dapat dinyatakan $r_{x y h i t u n g}>r_{x y t a b e l}$. Ini berarti nilai $\mathrm{r}_{\mathrm{xyhhitung}}$ signifikan dengan nilai 0,764 , sehingga $\mathrm{H}_{0}$ yang berbunyi tidak terdapat korelasi yang signifikan antara kemampuan berpikir kritis dengan penguasaan kompetensi pengetahuan IPS kelas IV SD Gugus I Mengwi Tahun Pelajaran 2017/2018 ditolak dan $\mathrm{H}_{\mathrm{a}}$ diterima. Jadi terdapat korelasi yang signifikan antara kemampuan berpikir kritis dengan penguasaan kompetensi pengetahuan IPS siswa kelas IV SD Gugus I Mengwi Tahun Pelajaran 2017/2018. Berdasarkan uraian yang telah dipaparkan dapat dikemukakan interprestasi, maka hal ini membuktikan bahwa rata-rata siswa kelas IV SD di Gugus I Mengwi tergolong memiliki kemampuan berpikir kritis dengan kategori sedang dan memperoleh nilai pengetahuan IPS dengan kategori sedang, hal ini berarti jika siswa memiliki kemampuan berpikir kritis yang tinggi maka nilai pengetahuan IPS yang diperoleh siswa juga akan tinggi.

Berdasarkan hal tersebut, kemampuan berpikir kritis sangat berpengaruh terhadap prestasi belajar siswa terutama dalam pembelajaran IPS. Karena dalam pembelajaran IPS lebih banyak mengkaji konsep atau masalah di lingkungan siswa. "Dalam kegiatan pembelajaran IPS, siswa dapat dibawa langsung ke dalam lingkungan alam sekitar, siswa akan akrab dengan kondisi setempat sehingga mengetahui makna serta manfaat mata pelajaran IPS secara nyata" (Gunawan 2011:41). Siswa yang memiliki kemampuan berpikir kritis yang tinggi akan lebih mudah untuk memecahkan masalah dalam pembelajaran khususnya pelajaran IPS. Siswa yang memiliki kemampuan berpikir kritis yang tinggi akan memanfaatkan potensinya dalam melihat masalah dan berusaha untuk memecahkannya. Hal ini juga diungkapkan oleh Darmina Pratiwi (2016, yang diakses pada tanggal 4 Januari 2018) yang menyatakan bahwa "Berpikir kritis adalah kemampuan untuk bernalar dalam suatu cara yang terorganisasi. Berpikir kritis memungkinkan untuk memanfaatkan potensi dalam melihat masalah, memecahkan masalah, menciptakan dan menyadari diri." Dalam mengikuti sebuah proses pembelajaran terkadang ada siswa yang belum maksimal atau belum berhasil dalam belajar. Berhasil atau tidaknya seseorang dalam belajar disebabkan oleh beberapa faktor yaitu faktor internal dan faktor eksternal. Salah satu faktor internal yang mempengaruhi keberhasilan siswa dalam menguasai kompetensi pengetahuan IPS salah satunya adalah intelegensi. Kemampuan berpikir kritis termasuk kedalam faktor internal yaitu intelegensi. Kemampuan berpikir kritis yang berbeda-beda antara siswa satu dengan yang lainnya akan memberikan hasil nilai penguasaan kompetensi pengetahuan IPS yang berbeda-beda pula. Apabila siswa memiliki kemampuan berpikir kritis yang kurang cenderung lebih sulit untuk memecahkan masalah dalam pembelajaran. Sementara siswa yang memiliki tingkat kemampuan berpikir kritis yang tinggi akan dapat menerima pembelajaran yang diberikan oleh guru dengan baik dan menguasai materi pembelajaran secara optimal.

Kemampuan berpikir kritis akan dapat dikembangkan melalui pembelajaran yang interaktif. Melalui pembelajaran yang interaktif dengan melibatkan siswa secara aktif dalam proses pembelajaran maka siswa akan mendapatkan kesempatan dalam menyampaikan pendapat, ide ataupun gagasan yang dimilikinya. Dengan begitu siswa akan menggali pengetahuannya sendiri dan pembelajaran tersebut akan lebih bermakna bagi siswa. Dengan memiliki kemampuan berpikir kritis siswa dapat lebih mudah memahami konsep, peka akan masalah yang terjadi sehingga dapat memahami dan menyelesaikan masalah, dan mampu mengaplikasikan konsep dalam situasi yang berbeda. "Kemampuan berpikir kritis siswa dapat ditumbuhkembangkan melalui proses mengamati, membandingkan, mengelompokkan, menghipotesis, mengumpulkan data, menafsirkan, menyimpulkan, menyelesaikan masalah, dan mengambil keputusan" Susanto (2013:127). Penelitian ini sejalan dengan penelitian yang dilakukan oleh Darmina Pratiwi Barus. Tahun 2016, dengan menggunakan taraf signifikansi 0,05 dan $\mathrm{n}=42$ dengan hasil $t_{\text {hitung }}>t_{\text {tabel, }}$ yaitu 11,47 $>1,68$ maka terdapat hubungan antara kemampuan berpikir kritis dengan kemampuan menulis teks berita pada siswa kelas IX SMP Negeri 6 Percut Sei Tuan Tahun Pembelajaran $2015 / 2016$. 


\section{Simpulan dan Saran}

Berdasarkan simpulan saran yang ingin disampaikan sebagai berikut:

(1) Kepada siswa, berdasarkan temuan penelitian yang diperoleh, disarankan kepada siswa untuk meningkatkan kemampuan berpikir kritis dalam belajar, sehingga siswa mampu memecahkan permasalahan yang dihadapi dalam proses pembelajaran terutamanya pelajaran IPS dan untuk meningkatkan prestasi belajar di sekolah.

(2) Kepada guru, berdasarkan temuan penelitian yang diperoleh, disarankan kepada guru agar dapat memberikan pembelajaran yang bervariasi dan kreatif. Karena pembelajaran yang kreatif akan membuat siswa terlatih dalam berpikir kritis. Guru sebaiknya menumbuhkan keberanian siswa dalam menyampaikan ide atau gagasan yang dimiliki. Melalui hal tersebut nantinya siswa yang memiliki kemampuan berpikir kritis akan mampu memecahkan suatu prmasalahan dalam pembelajaran.

(3) Kepada sekolah, berdasarkan temuan penelitian, disarankan kepada kepala sekolah agar dapat menggunakan hasil penelitian ini sebagai pendukung sumber belajar guru dalam meningkatkan kualitas pembelajaran dengan menumbuhkan kemampuan berpikir kritis siswa dalam belajar di sekolah sehingga sekolah mampu menghasilkan siswa yang berkualitas.

(4) Kepada peneliti lain, berdasarkan temuan penelitian, disarankan kepada peneliti agar hasil penelitian ini digunakan sebagai referensi untuk melaksanakan penelitian selanjutnya dan semoga penelitian ini bermanfaat bagi seluruh masyarakat yang menggunakan penelitian ini.

\section{Daftar Rujukan}

Agung, A. A. G. 2014. Metodelogi Penelitian Pendidikan. Singaraja: Fakultas Ilmu Pendidikan Universitas Pendidikan Ganesha.

Aunurrahman. 2012. Belajar Dan Pembelajaran. Bandung: Alfabeta

Arikunto, Suharsimi. 2015. Dasar-Dasar Evaluasi Pendidikan. Jakarta: PT. Bumi Aksara.

Barus, Pratiwi. 2016. "Hubungan Kemampuan Berpikir Kritis Dengan Kemampuan Menulis Teks Berita Pada Siswa Kelas IX SMP Negeri 6 Percut Sei Tuan". Diakses Pada Tanggal 4 Januari 2018

Ghofur, Durrotun Nafisah, dkk. 2016. "Gaya Belajar dan Implikasinya Terhadap Kemampuan Berpikir Kritis Mahasiswa. Volume 1. Nomor 2. Diakses Pada Tanggal 4 Januari 2018

Habibullah. 2014. Refleksi Gender dalam Pembelajaran Kurikulum 2013; Studi terhadap Hasil Belajar IPS Siswa Kelas Model di Solok, Sumatera Barat. Jurnal Ilmiah Kajian Gender Vol. 4 No. 2 Hal. 1-18. http://kafaah.org/index.php/kafaah/article/view/100/74. Diakses Pada Tanggal 4 Januari 2018.

Jihad, Asep dan Abdul Haris. 2012. Evaluasi Pembelajaran. Yogyakarta: Multi Pressindo.

Kosasih. 2014. Strategi Belajar Dan Pembelajaran. Bandung: Yrama Widya

Prihanti, Sekar. 2015. Strategi Belajar. Malang: Universitas Muhammadiyah Malang.

Purnomo, Arif, Abdul Muntholib, dan Syaiful Amin. 2016. Model Pembelajaran Ilmu Pengetahuan Sosial (IPS) PADA Materi Kontroversi (Controversy Issues) DI Sekolah Menengah Pertama (SMP) Kota Semarang. Jurnal Penelitian Pendidikan Vol. 33 No. 1 Hal. 13-25. https://journal.unnes.ac.id/nju/index.php/JPP/article/download/7661/5343. Diakses Pada Tanggal 4 Januari 2018.

Saputra, Targana Adi. 2016. Pembelajaran Ips Di Sekolah Dasar Berbasis Pembelajaran Tematik. Edu Humaniora Jurnal Pendidikan Dasar Vol. 1 No. 2 Hal. 1-8. http://ejournal.upi.edu/index.php/eduhumaniora/article/view/2736/1784. Diakses Pada Tanggal 4 Januari 2018.

Slameto. 2010. Belajar \& Faktor-Faktor Yang Mempengaruhi. Jakarta: Rineka Cipta. 
Sudijono, Anas. 2015. Pengantar Evaluasi Pendidikan. Jakarta: Rajawali Pers.

Susanto, Ahmad. 2013. Teori Belajar Dan Pembelajaran Di Sekolah Dasar. Jakarta: Kencana Prenada Media Group.

Surahman, Edy, dan Mukminan. 2017. Peran Guru IPS Sebagai Pendidik dan Pengajar dalam Meningkatkan Sikap Sosial dan Tanggung Jawab Sosial Siswa SMP. Jurnal Pendidikan IPS Vol. 4 No. 1 Hal. 1-13. http://journal.uny.ac.id/index.php/hsjpi. Diakses Pada Tanggal 4 Januari 2018. 